\title{
Vitamin D concentration and its association with parathyroid hormone in children and adolescents
}

\author{
Patricia Clark ${ }^{1,2 *}$, Diana Montiel-Ojeda ${ }^{1,2}$, Laura G. Chico-Barba², Desirée López-González ${ }^{1}$, \\ Lucía Méndez-Sánchez ${ }^{1,2}$, and Miguel A. Guagnelli-Martínez ${ }^{1,2}$ \\ ${ }^{1}$ Unidad de Epidemiología Clínica, Hospital Infantil Federico Gómez; ${ }^{2}$ Facultad de Medicina, Universidad Nacional Autónoma de México, Mexico \\ City, Mexico
}

\begin{abstract}
Background: Vitamin D (VD) deficiency has been inversely associated with parathyroid hormone (PTH) levels in the adult population but not in children and adolescents. This study aimed to report VD concentration and its correlation with PTH levels in a sample of healthy Mexican children. Methods: We conducted a cross-sectional study with 275 healthy Mexican subjects aged 2 to 17 years to estimate the status of 25-(OH)-D and its correlation with PTH levels. The 25-(OH)-D levels were estimated by liquid chromatography-tandem mass spectrometry and PTH by radioimmunoassay. Results: Subjects were categorized as young children (2 to 5 years), school children (6 to 10 years), and adolescents (11 to 17 years). The median concentration of 25-(OH)-D in young children was $27.4 \mathrm{ng} / \mathrm{ml}$; in school children, $25.6 \mathrm{ng} / \mathrm{ml}$; and adolescents, $24.7 \mathrm{ng} /$ $\mathrm{ml}$. VD levels $<20 \mathrm{ng} / \mathrm{ml}$ were found in only $10.5 \%$ of the participants. Only $3 \%$ of the young children showed VD deficiency, in contrast to $10 \%$ of school children and $21 \%$ of adolescents ( $p \leq 0.05)$. PTH was found within normal ranges in $95.6 \%$ of the studied population. VD levels $<20 \mathrm{mg} / \mathrm{dl}$ were found in $25.8 \%$ of children with overweight or obesity $(p=0.009)$. Conclusions: VD levels $<20 \mathrm{ng} / \mathrm{ml}$ were observed in $10 \%$ of the studied group, but this percentage increased with age: $21 \%$ of the adolescents showed VD levels $<20 \mathrm{ng} / \mathrm{ml}$. No correlation with PTH levels was found. The VD values reported in this study are lower than those previously reported in Mexican children.
\end{abstract}

Keywords: Vitamin D. Parathyroid hormone. Pediatrics.

\section{Concentración de vitamina $D$ y su relación con la hormona paratiroidea en niños y adolescentes}

\section{Resumen}

Introducción: La deficiencia de vitamina $D$ se ha asociado inversamente con la concentración de hormona paratiroidea (PTH) en los adultos, pero no en los niños y adolescentes. El objetivo de este estudio fue reportar la concentración de vitamina D y su correlación con la concentración de PTH en una muestra de niños mexicanos sanos. Métodos: Se llevó a cabo un estudio transversal con 275 mexicanos sanos de 2 a 17 años de edad en quienes se estimaron las concentraciones de 25-(OH)-D utilizando cromatografía líquida con espectrometría de masas y de PTH por radioinmunoensayo, y su correlación. Resultados: Los participantes se categorizaron como prescolares (2 a 5 años), escolares (6 a 10 años) y adolescentes

Correspondence:

*Patricia Clark

E-mail: osteoclark@gmail.com

Available online: 08-06-2021

Date of reception: 05-08-2020

Date of acceptance: 02-10-2020

DOI: 10.24875/BMHIM.20000243
Bol Med Hosp Infant Mex. 2021;78(4):265-272

www.bmhim.com

1665-1146/@ 2020 Hospital Infantil de México Federico Gómez. Published by Permanyer. This is an open access article under the CC BY-NC-ND license (http://creativecommons.org/licenses/by-nc-nd/4.0/). 
(11 a 17 años). La mediana de la concentración de 25-(OH)-D en los prescolares fue de $27.4 \mathrm{ng} / \mathrm{ml}$, en los escolares de $25.6 \mathrm{ng} / \mathrm{ml}$ y en los adolescentes de $24.7 \mathrm{ng} / \mathrm{ml}$. Solo en el 10.5\% de los participantes se encontraron valores de vitamina $D<20 \mathrm{ng} / \mathrm{ml}$. En contraste con el 10\% de los escolares y el $21 \%$ de los adolescentes, solo el $3 \%$ de los prescolares mostraron deficiencia de vitamina $D(p \leq 0.05)$. La PTH se encontró dentro de los límites normales en el $95.6 \%$ de la población estudiada. Se encontraron concentraciones de vitamina $D<20 \mathrm{mg} / \mathrm{dl}$ en el $25.8 \%$ de los niños con sobrepeso y obesidad $(p=0.009)$. Conclusiones: Solo en el $10 \%$ de los participantes se encontraron concentraciones de vitamina $D<20 \mathrm{ng} / \mathrm{ml}$, pero este porcentaje aumento con la edad y se hallaron valores < $20 \mathrm{ng} / \mathrm{ml}$ en el $21 \%$ de los adolescentes. La PTH se encontró dentro de los valores normales. Las concentraciones de vitamina $D$ en este estudio resultaron menores que las previamente reportadas en niños mexicanos.

Palabras clave: Vitamina D. Hormona paratiroidea. Pediatría.

\section{Introduction}

Growing attention has been given to vitamin D (VD) and children's health over the past two decades. VD deficiency has been described as one of the most significant impact health problems in the pediatric population ${ }^{1-3}$. The prevalence of VD deficiency ranges from 60 to $80 \%$ worldwide in children ${ }^{1,2,4,5}$. In Mexico, deficiencies in up to $20 \%$ have been reported in this population $^{3,6-8}$.

Several factors have been associated with VD levels in humans, such as nutritional status, skin color, geographic localization, and exposure to sunlight ${ }^{9,10}$. VD deficiency can result in severe health problems, such as abnormalities in calcium and phosphorus uptake and bone metabolism ${ }^{11-13}$.

Besides VD's importance for calcium homeostasis and bone growth, its deficiency has also been associated with the risk of other pathologies, such as type 1 diabetes in children and type 2 diabetes in adults ${ }^{14-16}$. Moreover, VD deficiency has been related to increased systolic pressure, low serum calcium levels, and HDL cholesterol in the adult population ${ }^{17,18}$. In children, frequent infections can identify VD deficiency since it has been associated with low immunity ${ }^{19,20}$.

VD has another essential role in calcium metabolism. Only $10-15 \%$ of dietary calcium is absorbed through the intestinal tract when low VD levels are present ${ }^{21}$. Moreover, when calcium and 25-(OH)-D serum levels are low, PTH is activated to stimulate 1,25-(OH)-D production and increase calcium absorption through the gut, causing an inverse correlation between PTH and VD levels ${ }^{13,22}$.

In a previous report ${ }^{8}$, we found a prevalence of VD deficiency $>40 \%$ and an inverse relation with PTH levels in Mexican adults. Although some studies have reported VD concentrations in Mexican children, their association with PTH levels ${ }^{3,7}$ has not been addressed, although this association has been demonstrated in children in other countries ${ }^{23,24}$.

Therefore, this study aimed to report VD concentrations in a group of healthy Mexican children between 2-17 years of age and their correlation with PTH levels with a methodology previously used in Mexican adults ${ }^{8}$.

\section{Methods}

\section{Study population}

We conducted a cross-sectional study with 275 children and adolescents from Toluca City, State of Mexico (Estado de México), and Mexico City between March and September 2013. The participants were healthy children and adolescents from day-care centers, public and private schools, and children accompanying their siblings to the dental service at the Centro de Especialidades Odontológicas outpatient clinic Instituto Materno Infantil de Toluca.

Children who agreed to participate in the study underwent a complete medical history to verify their health. Subjects with symptoms of infection in the two weeks before sampling and subjects with chronic inflammatory diseases were excluded.

This investigation was conducted according to the Helsinki Declaration of Clinical Research on Humans ${ }^{25}$ and was reviewed and approved by the Institutional Research, Ethics and Biosafety Committee at the Hospital Infantil de Mexico Federico Gómez (HIM/2012/013). Parents or legal guardians who agreed to participate were asked to provide written informed consent, and children over 7 years provided an assenting letter.

\section{Subjects}

Demographic characteristics such as age, sex, family, personal pathological history, and factors associated 
with bone health were collected in a complete medical history applied to parents/guardians. Weight $(\mathrm{kg})$ was measured with a calibrated SECA brand scale with participants being barefoot and wearing minimal clothing. Height $(m)$ was measured using a conventional SECA brand stadiometer while the participants were standing barefoot with their shoulders in a relaxed position. Body mass index (BMI) was computed as a ratio of weight $(\mathrm{kg})$ to height squared $\left(\mathrm{m}^{2}\right)$. The Z-score values established by the World Health Organization (WHO) were used to determine BMI. Overweight was defined with a Z-score $\geq 1$; obesity, Z-score $\geq 2$; low weight, Z-score $\leq-2$; and extremely low weight, Z-score $\leq-3^{26}$.

Skin tone was characterized according to Fitzpatrick sun-reactive skin types I to VI: I and II, very sensitive; III, sensitive; IV, moderately sensitive; V, little sensitive; and $\mathrm{VI}$, very little sensitive ${ }^{27}$. A calcium intake evaluation was performed with a semi-quantitative food questionnaire previously validated for the Mexican population ${ }^{28}$.

After an 8-hour fast, blood samples $(6 \mathrm{ml})$ were collected to determine 25-(OH)-D and PTH levels. For 25-(OH)-D determinations, a stable isotope-labeled internal standard was used in liquid chromatography-tandem mass spectrometry $(\mathrm{LC} / \mathrm{MS})^{29}$ at the Metabolism Laboratory, Tufts University Medical Center in Boston, United States. PTH levels were determined by radioimmunoassay (RIA) in the Endocrinology Laboratory, Hospital Infantil de Mexico Federico Gómez (HIMFG). The 25-(OH)-D cutoff points were determined by the Institute of Medicine $(\mathrm{IOM})^{30}$.

All evaluations were conducted in the Clinical Epidemiology Research Unit of the HIMFG and Instituto de Seguridad Social del Estado de México (ISSEMyM), Toluca City. The handling of samples was regulated according to the Guidelines of managing samples for diagnostic measures (REMU-MA-01) ${ }^{31}$.

\section{Statistical analysis}

The type of distribution of the variables was determined using the Kolmogorov-Smirnov test. Medians with interquartile ranges were calculated for continuous variables. Frequencies and percentages were obtained from the categorical variables.

Age subgroups were classified as follows: young children (aged between 2 to 5 years), school children (between 6 to 10 years), and adolescents (between 11 to 17 years old). Spearman's correlation was performed to determine the association between 25-(OH)-D and PTH levels.
VD serum levels were classified into four subgroups according to IOM-established criteria: $\geq 30 \mathrm{ng} / \mathrm{ml}$, 20-29 ng/ml, $11-19 \mathrm{ng} / \mathrm{ml}$, and $<11 \mathrm{ng} / \mathrm{ml}$.

Finally, we performed a median difference test to evaluate differences between the groups according to their BMI category and differences between calcium intake and age group.

In all cases, a $p$-value $<0.05$ was considered significant. All statistical analyses were performed using SPSS version 20.0 program for Windows (SPSS Inc., Chicago, IL).

\section{Results}

From a total of 275 participants, $55 \%$ were male. The median age for each group was 4 years in young children, 8 years in school children, and 13 years in adolescents.

The median weight was $16.0 \mathrm{~kg}$ in the group of young children, $25.3 \mathrm{~kg}$ in school children, and $47.8 \mathrm{~kg}$ in adolescents. According to the BMI Z-score, $68 \%$ of the sample was in a normal weight range, and $26.9 \%$ with overweight or obesity (Table 1).

The median $(\mathrm{Cl} 95 \%)$ concentration levels of $25-(\mathrm{OH})-\mathrm{D}$ in young children were $27.4 \mathrm{ng} / \mathrm{ml}(24.7-$ $31.0 \mathrm{ng} / \mathrm{ml}$ ); in school children, $25.6 \mathrm{ng} / \mathrm{ml}$ (23.2$31.3 \mathrm{ng} / \mathrm{ml}) ;$ and adolescents, $24.7 \mathrm{ng} / \mathrm{ml}(21.2-29.4 \mathrm{ng} / \mathrm{ml})$. Only $10.5 \%$ of the participants showed $25-(\mathrm{OH})-\mathrm{D}$ levels $<20 \mathrm{ng} / \mathrm{ml}$. None of the participants showed $25-(\mathrm{OH})-\mathrm{D}$ levels $<11 \mathrm{ng} / \mathrm{ml}$. Most of the participants $(62.2 \%)$ showed levels between 20 and $29 \mathrm{ng} / \mathrm{ml}$, while $27.3 \%$ showed levels $>30 \mathrm{ng} / \mathrm{ml}$. PTH was found in normal ranges in $95.6 \%$ of the sample (Table 2).

When we analyzed the frequency in each $25-(\mathrm{OH})-\mathrm{D}$ levels subgroup, we found $11 \%$ of the participants in the $12-19 \mathrm{ng} / \mathrm{ml}$ group, $61 \%$ in the $20-30 \mathrm{ng} / \mathrm{ml}$ group, and $28 \%$ in the $>30 \mathrm{ng} / \mathrm{ml}$ group. When performing the same analysis according to age groups, we found statistically significant differences in the $12-19 \mathrm{ng} / \mathrm{ml}$ subgroup in which only $3 \%$ of the young children were included. In contrast, $10 \%$ of school children and $21 \%$ of adolescents were found in this subgroup $(p \leq 0.05)$. We found no statistically significant differences in either the $20-30 \mathrm{ng} / \mathrm{ml}$ or the $>30 \mathrm{ng} / \mathrm{ml}$ subgroups by age.

Most of the children and adolescents showed PTH levels according to 25-(OH)-D concentrations groups within the normal range. No significant differences were found between age groups (Table 3 ). When analyzing the association between 25-(OH)-D concentration and PTH levels, a weak inverse association was observed although not statistically significant $(r h o=-0.112, p=0.063)$. 
Table 1. Baseline characteristics of the participants by age group

\begin{tabular}{|c|c|c|c|}
\hline \multicolumn{4}{|c|}{ Median (CI 95\%) } \\
\hline Variables & $\begin{array}{l}\text { Young children } \\
\quad(n=53)\end{array}$ & $\begin{array}{l}\text { School children } \\
\quad(n=132)\end{array}$ & $\begin{array}{l}\text { Adolescents } \\
\quad(\mathrm{n}=90)\end{array}$ \\
\hline $\begin{array}{l}\text { Age (years) } \\
\text { Min-Max }\end{array}$ & $\begin{array}{c}4(3-5) \\
2-5\end{array}$ & $\begin{array}{c}8(7-9) \\
6-10\end{array}$ & $\begin{array}{c}13(12-14) \\
11-17\end{array}$ \\
\hline $\begin{array}{l}\text { Sex, } n(\%) \\
\text { Male } \\
\text { Female }\end{array}$ & $\begin{array}{l}25(47.2 \%) \\
28(52.8 \%)\end{array}$ & $\begin{array}{l}70(53 \%) \\
62(47 \%)\end{array}$ & $\begin{array}{l}56(62.2 \%) \\
34(37.8 \%)\end{array}$ \\
\hline $\begin{array}{l}\text { Weight }(\mathrm{kg}) \\
\text { Min-Max }\end{array}$ & $\begin{array}{c}16.0(13.8-18.0) \\
10.5-34.3\end{array}$ & $\begin{array}{c}25.3(22.0-32.2) \\
14.1-56.0\end{array}$ & $\begin{array}{c}47.8(36.4-55.0) \\
16.4-87.5\end{array}$ \\
\hline $\begin{array}{l}\text { Height }(\mathrm{cm}) \\
\text { Min-Max }\end{array}$ & $\begin{array}{c}102.8(96.8-106.9) \\
83.2-119.3\end{array}$ & $\begin{array}{c}125.2(118.2-132.3) \\
99.3-153.4\end{array}$ & $\begin{array}{c}152.70(145.7-161.0) \\
105.5-180.0\end{array}$ \\
\hline $\begin{array}{l}\text { Body mass index (BMI), } n(\%) \\
\text { Under weight } \\
\text { Normal weight } \\
\text { Overweight } \\
\text { Obesity }\end{array}$ & $\begin{array}{c}5(9.4 \%) \\
39(73.6 \%) \\
4(7.5 \%) \\
5(9.4 \%)\end{array}$ & $\begin{array}{c}3(2.3 \%) \\
86(65.2 \%) \\
22(16.7 \%) \\
21(15.9 \%)\end{array}$ & $\begin{array}{c}6(6.7 \%) \\
62(68.9 \%) \\
15(16.7 \%) \\
7(7.8 \%)\end{array}$ \\
\hline $\begin{array}{l}\text { Skin type, } n \text { (\%) } \\
\text { Extremely sensitive (I) } \\
\text { Very sensitive (II) } \\
\text { Sensitive (III) } \\
\text { Moderate sensitive (IV) } \\
\text { Low sensitive (V) } \\
\text { Very low sensitive (VI) }\end{array}$ & $\begin{array}{c}0(0 \%) \\
0(0 \%) \\
8(15.1 \%) \\
35(66 \%) \\
10(18.9 \%) \\
0(0 \%)\end{array}$ & $\begin{array}{c}0(0 \%) \\
0(0 \%) \\
8(6.1 \%) \\
64(48.5 \%) \\
60(45.5 \%) \\
0(0 \%)\end{array}$ & $\begin{array}{c}3(3.3 \%) \\
5(5.6 \%) \\
11(12.2 \%) \\
41(45.6 \%) \\
30(33.3 \%) \\
0(0 \%)\end{array}$ \\
\hline $\begin{array}{l}\text { Calcium consumption (mg/day) } \\
\text { Min-Max }\end{array}$ & $\begin{array}{c}947.1(541.8-1481.0) \\
101.7-3548.7\end{array}$ & $\begin{array}{c}783.1(452.3-1107.9) \\
28.6-3669.6\end{array}$ & $\begin{array}{c}440.3(259.3-932.8) \\
38.1-2327.6\end{array}$ \\
\hline $\begin{array}{l}\text { Serum concentrations } \\
\text { 25-(OH)-D ng/ml } \\
\text { Min-Max } \\
\text { 25-(OH)-D nmol/l } \\
\text { Min-Max } \\
\text { PTH (pg/ml) } \\
\text { Min-Max }\end{array}$ & $\begin{array}{c}27.4(24.7-31.0) \\
19.1-48.3 \\
68.5(61.8-77.5) \\
47.9-120.7 \\
22.4(17.9-29.7) \\
5.1-80.8\end{array}$ & $\begin{array}{c}25.6(23.2-31.3) \\
11.9-58.3 \\
64.1(58.1-78.4) \\
29.7-145.7 \\
25.0(19.5-32.7) \\
4.1-85.5\end{array}$ & $\begin{array}{c}24.7(21.2-29.4) \\
12.9-41.5 \\
61.9(52.7-73.5) \\
32.3-103.8 \\
24.3(19.4-31.3) \\
2.0-62.0\end{array}$ \\
\hline
\end{tabular}

25-(OH)-D, 25-hydroxivitamin D; Cl, confidence interval; PTH, parathyroid hormone.

Table 2. Status of 25-(OH)-D levels per age group and sex in healthy Mexican children

\begin{tabular}{|c|c|c|c|c|c|c|c|c|c|}
\hline \multirow[t]{2}{*}{ 25-OH-D levels } & \multicolumn{3}{|c|}{ Male $(n=151)$} & \multicolumn{3}{|c|}{ Female $(n=124)$} & \multicolumn{3}{|c|}{ Total $(n=275)$} \\
\hline & $2-5 y$ & 6-11 y & $12-17 y$ & $2-5 y$ & 6-11 y & $12-17 y$ & $2-5 y$ & 6-11 y & $12-17 y$ \\
\hline$\geq 30(\mathrm{ng} / \mathrm{ml})$ & $7(28 \%)$ & $21(30 \%)$ & $13(23.2 \%)$ & $11(39.3 \%)$ & $18(29 \%)$ & $5(14.7 \%)$ & $18(34 \%)$ & $39(29.5 \%)$ & $18(20 \%)$ \\
\hline $20-29$ (ng/ml) & $17(68 \%)$ & $44(62.9 \%)$ & $37(66.1 \%)$ & $17(60.7 \%)$ & $37(59.7 \%)$ & $19(55.9 \%)$ & $34(64.2 \%)$ & $81(61.4 \%)$ & $56(62.2 \%)$ \\
\hline $12-19$ (ng/ml) & $1(4 \%)$ & $5(7.1 \%)$ & $6(10.7 \%)$ & $0(0 \%)$ & $7(11.3 \%)$ & $10(29.4 \%)$ & $1(1.9 \%)$ & $12(9.1 \%)$ & $16(17.8 \%)$ \\
\hline$\leq 11(\mathrm{ng} / \mathrm{ml})$ & $0(0 \%)$ & $0(0 \%)$ & $0(0 \%)$ & $0(0 \%)$ & $0(0 \%)$ & $0(0 \%)$ & $0(0 \%)$ & $0(0 \%)$ & $0(0 \%)$ \\
\hline
\end{tabular}

We also analyzed the concentration of $25-(\mathrm{OH})-\mathrm{D}$ according to the BMI (Table 4). We found BMI in a normal range in over half of the population $(64.2 \%)$ with 25-(OH)-D levels between 20 to $29 \mathrm{ng} / \mathrm{ml}$.
When we analyzed the association between 25-(OH)-D and PTH levels by age group, no statistically significant differences were found. We also analyzed the association between BMI and VD levels. 
Table 3. Parathyroid hormone levels according to 25-(OH)-D levels by age group

\begin{tabular}{|c|c|c|c|c|c|c|c|}
\hline \multirow[t]{2}{*}{ Age group } & \multicolumn{2}{|c|}{$10-20 \mathrm{ng} / \mathrm{ml}$} & \multicolumn{2}{|c|}{$20-29 \mathrm{ng} / \mathrm{ml}$} & \multicolumn{2}{|c|}{$\geq 30 \mathrm{ng} / \mathrm{ml}$} & \multirow[t]{2}{*}{$p$-values* } \\
\hline & Median & IOR & Median & IOR & Median & IOR & \\
\hline Young children (2-5 y) & 26.4 & $24.7-28$ & 25.0 & $19.6-36$ & 19.6 & $17.9-26.4$ & 0.09 \\
\hline School children (6-11 y) & 28.7 & $17.3-37.2$ & 26.1 & $20.6-32.5$ & 22.6 & $18.0-32.1$ & 0.43 \\
\hline Adolescents (12-17 y) & 28.4 & $18.4-31.9$ & 22.5 & $16.3-30.5$ & 23.5 & $19.4-27.6$ & 0.80 \\
\hline
\end{tabular}

*Kruskal-Wallis test.

IQR, interquartile range; PTH, parathyroid hormone.

Table 4. 25-OH-D and PTH level median difference according to the BMI

\begin{tabular}{|c|c|c|c|c|c|c|}
\hline \multirow[t]{2}{*}{ Age group } & & \multicolumn{2}{|c|}{ BMI Z-score < 1} & \multicolumn{2}{|c|}{ BMI Z-score $\geq 1$} & \multirow[t]{2}{*}{$p$-values* } \\
\hline & & Median & IOR & Median & IOR & \\
\hline \multirow{2}{*}{$\begin{array}{l}\text { Young children } \\
(2-5 y)\end{array}$} & 25-OH-D levels (ng/ml) & 27.4 & $24.7-31.3$ & 26.5 & $21.8-30.9$ & 0.8 \\
\hline & PTH levels (pg/ml) & 22.4 & $19.3-33$ & 23.1 & $17.9-29.7$ & 0.9 \\
\hline \multirow{2}{*}{$\begin{array}{l}\text { School children } \\
(6-10 \mathrm{y})\end{array}$} & 25-OH-D levels (ng/ml) & 26.0 & $24-31.1$ & 24.9 & 20.9-32.1 & 0.3 \\
\hline & PTH levels (pg/ml) & 26.0 & $20.1-33.2$ & 24.7 & $18.1-32$ & 0.5 \\
\hline \multirow{2}{*}{$\begin{array}{l}\text { Adolescents } \\
(11-17 \mathrm{y})\end{array}$} & 25-OH-D levels (ng/ml) & 24.8 & $21.0-29.7$ & 24.8 & $20.9-28.2$ & 0.8 \\
\hline & PTH levels (pg/ml) & 24.5 & $18-31.3$ & 20.7 & $15.9-26.2$ & 0.2 \\
\hline
\end{tabular}

*Mann-Whitney's U-test.

BMI, body mass index; IQR, interquartile range; PTH, parathyroid hormone.

$25-(\mathrm{OH})$-D levels $>20 \mathrm{ng} / \mathrm{ml}$ were observed in $74.2 \%$ of participants in the normal or low BMI groups and $25.8 \%$ of participants with overweight or obesity $(p=0.009)$.

Finally, we analyzed dietary calcium intake in this population and found that $49 \%$ of the population consumed $<700 \mathrm{mg} /$ day, with the adolescents group being the one with the lowest intake (Table 5). Besides, only $18 \%$ of adolescents reported calcium intake levels $>1300 \mathrm{mg} /$ day $(p=0.001)$ (Figure 1).

\section{Discussion}

In the present study, we described VD concentrations and their association with PTH levels in a group of healthy children and adolescents from the Mexico City metropolitan area and Toluca City. This study is the first to explore this association in Mexican children to the extent of our knowledge. This study follows the same methodology that we previously followed to report VD levels and their association with PTH in a sample of Mexican adults ${ }^{8}$. As the present

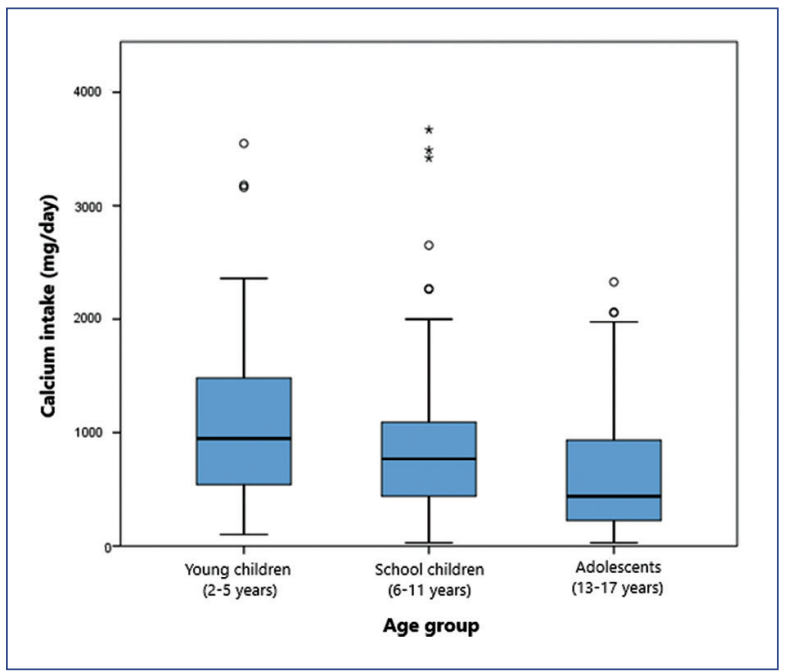

Figure 1. Calcium intake (mg/day) per age group.

group of children and adolescents came from the same cities as the adults studied previously, and the same techniques and laboratories were used in both 
Table 5. Frequency of calcium intake by age groups according to the Institute of Medicine recommendations

\begin{tabular}{|l|c|c|c|}
\hline $\begin{array}{l}\text { Calcium } \\
\text { daily intake } \\
\text { (mg/day) }\end{array}$ & $\begin{array}{c}\text { Young } \\
\text { children } \\
\text { (2-5 years old) }\end{array}$ & $\begin{array}{c}\text { School } \\
\text { children } \\
\text { (6-10 years old) }\end{array}$ & $\begin{array}{c}\text { Adolescents } \\
\text { (11-17 years } \\
\text { old) }\end{array}$ \\
\hline$\leq 700$ & $16(30.2 \%)$ & $61(46.2 \%)$ & $58(64.4 \%)$ \\
\hline 700 to 1000 & $13(24.5 \%)$ & $30(22.7 \%)$ & $12(13.3 \%)$ \\
\hline 1000 to 1300 & $10(18.9 \%)$ & $20(15.2 \%)$ & $3(3.3 \%)$ \\
\hline$\geq 1300$ & $14(26.9 \%)$ & $21(15.9 \%)$ & $17(18.9 \%)$ \\
\hline
\end{tabular}

studies (LC/MS for 25-(OH)-D and RIA for PTH), the results of both groups can be complemented and compared with each other ${ }^{8}$.

We found VD deficiency among Mexican children/ adolescents aged from 2 to 17 years: $10 \%$ of the participants showed $<20 \mathrm{ng} / \mathrm{ml}$ values. We found $<10 \mathrm{ng} / \mathrm{dl}$ levels in one case.

No statistically significant association was found between PTH and 25-(OH)-D levels, although an inverse relationship trend ( $r h o=-0.112, p=0.063$ ) was identified. Possibly, we need a larger sample to find a statistically significant difference since the correlation between PTH and 25-(OH)-D in the pediatric population has been demonstrated by Clark et al., Sahin et al., and Asghari et al. ${ }^{8,23,24}$.

Only a few studies have described VD levels in children and adolescents in Mexico. Toussaint et al. ${ }^{3}$ reported VD deficiency in $24.7 \%$ of children aged 3 to 8 years, whereas our results showed VD deficiency in only $5 \%$ of children at this age range. The observed differences could be related to the participants' recruitment procedure. While Toussaint et al. ${ }^{3}$ participants were recruited in four different hospitals within the metropolitan area of Mexico City, our study recruited healthy children from day-care centers, schools, and the waiting room of dental offices. Moreover, a different technique was performed to measure $25-(\mathrm{OH})-\mathrm{D}$ in both reports: our study used LC/MS, while Toussaint's used quantitative electrochemiluminescence analysis (ECLIA).

A similar situation occurred with the study by Flores et al. ${ }^{7}$, which included a randomized sample of children (2 to 12 years old) recruited at the 2006 National Health and Nutrition Survey (ENSANUT). They reported VD levels $<20 \mathrm{ng} / \mathrm{dl}$ in $30 \%$ of young children (2-5 years old) and $18 \%$ of school children (6-12 years old). Like the previous study ${ }^{3}$, we cannot compare the population recruited by Flores et al. ${ }^{7}$ with the present population because they included a broader range of regions of the country. Several of these areas are known for having high food insecurity and malnutrition ${ }^{32}$. Also, the representation of children coming from Mexico City and the metropolitan area was small. Finally, different techniques were used to analyze VD levels (enzyme-linked immunosorbent assay vs. LC/MS).

It is known that overweight and obesity are associated with low levels of 25-(OH)-D. Consistent with this association, we observed that $25.8 \%$ of children and adolescents with a weight-for-age Z-score $>1$ presented VD levels $<20 \mathrm{ng} / \mathrm{ml}$, similar to those reported previously by Elizondo et al. ${ }^{6}$, who found $27.3 \%$ of children with overweight and obesity with low levels of VD in the north of Mexico.

We found $25-(\mathrm{OH})$-D levels $<20 \mathrm{ng} / \mathrm{ml}$ in $17.8 \%$ of adolescents. Indeed, this group presented the highest prevalence of deficiency in our study. This finding may be explained by lifestyle changes related to adolescence. Ekelund et al. and Mitchell et al. ${ }^{33,34}$ reported that sedentary behavior (i.e., screen time, among others) increases with age, a pattern already described in Mexican adolescents ${ }^{35}$. Such trends include unhealthy dietary habits with potentially harmful effects on longterm health.

Our study found a trend toward less calcium intake as age increased. The group of adolescents reported dietary calcium intake below the minimum recommended $\left(700 \mathrm{mg}\right.$ ) by the Institute of Medicine ${ }^{30}$. The low daily calcium intake has been reported among adolescents in other studies as well ${ }^{36,37}$. However, this finding must be taken cautiously since measuring nutrients intake by questionnaires has sometimes been proven inaccurate. For example, children and adolescents tend to under-report their intake, as much as $67 \%$ below the actual intake, and females are more prone to under-report the dietary intake ${ }^{38,39}$. Conversely, we found calcium intake deficiency in $28 \%$ of adolescent females compared to $17 \%$ in males.

One limitation of our study is that the overall population in Mexico was not represented since our sample was limited to Mexico City and its surroundings. Therefore, data extrapolation to the rest of the country was not possible. Future studies with a broader representation of the country's different geographical areas should be conducted using the same methodology, including 25-(OH)-D and PTH measurement techniques 
to improve the knowledge of VD deficiency in other regions within Mexico.

In the present study, we found a low prevalence of VD deficiency in a sample of healthy children and adolescents in Mexico, where only $10 \%$ of the total sample showed VD levels $<20 \mathrm{ng} / \mathrm{ml}$. A higher prevalence was observed as age increased. These results are lower than those previously reported in a Mexican population, probably due to heterogeneity in the sample and the different techniques used to quantify $25-(\mathrm{OH})-\mathrm{D}$. We also observed VD levels $<20 \mathrm{ng} / \mathrm{dl}$ in $26 \%$ of subjects with overweight or obesity. Therefore, particular attention should be paid to this risk group due to the clinical implications associated with VD deficiency. Finally, although the correlation between the decrease in VD and the proportional increase in PTH was not significant in this study, more studies with a larger sample should be conducted on Mexican children. Recommendations for a healthy diet and lifestyle should be emphasized during this critical period of life because of future adulthood and old age implications.

\section{Ethical disclosures}

Protection of human and animal subjects. The authors declare that no experiments were performed on humans or animals for this study.

Confidentiality of data. The authors declare that they have followed the protocols of their work center on patient data publication.

Right to privacy and informed consent. The authors have obtained the written informed consent of the patients or subjects mentioned in the article. The corresponding author has this document.

\section{Conflicts of interest}

The authors declare no conflict of interest.

\section{Funding}

Federal funds: HIM2012/0113 SSA1011.

\section{Acknowledgments}

The authors thank Mexican families who took part in this study and the PhD and MSc in Medical Sciences, Odontology and Health in UNAM, since alumni from this program participated in this project (DMO and GCB).

\section{References}

1. Cediel G, Pacheco-Acosta J, CastiUo-Durdn C. Vitamin D deficiency in pediatric clinical practice. Arch Argent Pediatr. 2018;116:e75-81.

2. Misra M, Pacaud D, Petryk A, Collett-Solberg PF, Kappy M; Drug and Therapeutics Committee of the Lawson Wilkins Pediatric Endocrine Society. Vitamin D deficiency in children and its management: review of current knowledge and recommendations. Pediatrics. 2008; 122:398-417.

3. Toussaint-Martínez de Castro G, Guagnelli MA, Clark P, Méndez-Sánchez L, López-González D, Galán-Herrera JF, et al. Vitamin D, not iron, is the main nutrient deficiency in pre-school and school-aged children in Mexico City: a cross-sectional study. Nutr Hosp. 2016;33:372.

4. Brito A, Cori H, Olivares M, Mujica MF, Cediel G, López de Romaña D. Less than adequate vitamin $D$ status and intake in Latin America and the Caribbean: a problem of unknown magnitude. Food Nutr Bull. 2013; 34:52-64.

5. Palacios C, Gonzalez L. Is vitamin D deficiency a major global public health problem? J Steroid Biochem Mol Biol. 2014;144:138-45.

6. Elizondo-Montemayor L, Ugalde-Casas PA, Serrano-González M, CueIlo-García CA, Borbolla-Escoboza JR. Serum 25-hydroxyvitamin D concentration, life factors and obesity in Mexican children. Obesity (Silver Spring). 2010;18:1805-11.

7. Flores M, Macias N, Lozada A, Sánchez LM, Díaz E, Barquera S. Serum 25-hydroxyvitamin $D$ levels among Mexican children ages 2 y to 12 y: a national survey. Nutrition. 2013;29:802-4.

8. Clark P, Vivanco-Muñoz N, Talavera-Piña J, Rivas-Ruiz R, Huitrón G, Chico-Barba $G$, et al. High prevalence of hypovitaminosis $D$ in Mexicans aged 14 years and older and its correlation with parathyroid hormone. Arch Osteoporos. 2015;10:225

9. Holick MF. Sunlight and vitamin D for bone health and prevention of autoimmune diseases, cancers, and cardiovascular disease. Am J Clin Nutr. 2004;80:1678S-88S.

10. Calvo MS. Monitoring vitamin D status and intake in the US population: essential to understanding the role of vitamin $D$ in health. Am J Clin Nutr. 2019;110:6-7.

11. Holick MF. The vitamin D deficiency pandemic: approaches for diagnosis, treatment and prevention. Rev Endocr Metab Disord. 2017;18:153-65.

12. Holick MF, Binkley NC, Bischoff-Ferrari HA, Gordon CM, Hanley DA, Heaney RP, et al. Evaluation, treatment, and prevention of vitamin D deficiency: an Endocrine Society clinical practice guideline. J Clin Endocrinol Metab. 2011;96:1911-30.

13. Bouillon R, Carmeliet G. Vitamin D insufficiency: definition, diagnosis and management. Best Pract Res Clin Endocrinol Metab. 2018;32:669-84.

14. Lucato P, Solmi M, Maggi S, Bertocco A, Bano G, Trevisan C, et al. Low vitamin $D$ levels increase the risk of type 2 diabetes in older adults: a systematic review and meta-analysis. Maturitas. 2017;100:8-15.

15. Sacerdote A, Dave P, Lokshin V, Bahtiyar G. Type 2 diabetes mellitus, insulin resistance, and vitamin D. Curr Diab Rep. 2019;19:101.

16. Infante M, Ricordi C, Sanchez J, Clare-Salzler MJ, Padilla N, Fuenmayor $\mathrm{V}$, et al. Influence of vitamin $\mathrm{D}$ on islet autoimmunity and beta-cell function in type 1 diabetes. Nutrients. 2019;11:2185.

17. Matyjaszek-Matuszek B, Lenart-Lipinska M, Wozniakowska E. Clinical implications of vitamin D deficiency. Prz Menopauzalny. 2015;14:75-81.

18. Bikle DD. Vitamin D metabolism, mechanism of action, and clinical applications. Chem Biol. 2014;21:319-29.

19. Yakoob MY, Salam RA, Khan FR, Bhutta ZA. Vitamin D supplementation for preventing infections in children under five years of age. Cochrane Database Syst Rev. 2016:11:CD008824.

20. Prietl B, Treiber G, Pieber TR, Amrein K. Vitamin D and immune function. Nutrients. 2013;5:2502-21.

21. Khazai N, Judd SE, Tangpricha V. Calcium and vitamin D: skeletal and extraskeletal health. Curr Rheumatol Rep. 2008;10:110-7.

22. Galesanu C, Mocanu V. Vitamin D deficiency and the clinical consequences. Rev Med Chir Soc Med Nat lasi. 2015;119:310-8.

23. Asghari G, Yuzbashian E, Wagner CL, Mahdavi M, Shamsi R, Hosseinpanah $F$, et al. The relation between circulating levels of vitamin $D$ and parathyroid hormone in children and adolescents with overweight or obesity: quest for a threshold. PLoS One. 2019;14:e0225717.

24. Sahin ON, Serdar M, Serteser M, Unsal I, Ozpinar A. Vitamin D levels and parathyroid hormone variations of children living in a subtropical climate: a data mining study. Ital J Pediatr. 2018;44:40.

25. World Medical Association. Declaration of Helsinki: ethical principles for medical research involving human subjects. JAMA. 2013;310:2191-4.

26. Kuczmarski RJ, Ogden CL, Grummer-Strawn LM, Flegal KM, Guo SS, Wei R, et al. CDC growth charts: United States. Adv Data. 2000:1-27.

27. Fitzpatrick TB. The validity and practicality of sun-reactive skin types I through VI. Arch Dermatol. 1988;124:869-71.

28. Hernández-Avila M, Romieu I, Parra S, Hernández-Avila J, Madrigal H, Willett W. Validity and reproducibility of a food frequency questionnaire to assess dietary intake of women living in Mexico City. Salud Publica Mex. 1998;40:133-40. 
29. Maunsell Z, Wright DJ, Rainbow SJ. Routine isotope-dilution liquid chromatography-tandem mass spectrometry assay for simultaneous measurement of the 25-hydroxy metabolites of vitamins D2 and D3. Clin Chem. 2005:51:1683-90.

30. Institute of Medicine (US) Committee to Review Dietary Reference Intakes for Vitamin D and Calcium. Dietary Reference Intakes for Calcium and Vitamin D. Editors: Ross AC, Taylor CL, Yaktine AL, Del Valle HB. Washington DC: National Academies Press; 2011.

31. Díaz Quiñonez JA. Manual para la toma, envío y recepción de muestras para diagnósticp (REMU-MA-01). Instituto de Diagnóstico y Referencia Epidemiológicos Dr Manuel Martínez Báez. Mexico City: Dirección General de Epidemiología; 2015. Available from: www.censida.salud.gob.mx

32. Mundo-Rosas V, Unar-Munguia M, Hernández FM, Perez-Escamilla R, Shamah-Levy T. [Food security in Mexican households in poverty, and its association with access, availability and consumption]. Salud Publica Mex. 2019;61:866-75.

33. Mitchell JA, Pate RR, Beets MW, Nader PR. Time spent in sedentary behavior and changes in childhood BMI: a longitudinal study from ages 9 to 15 years. Int J Obes (Lond). 2013;37:54-60.
34. Ekelund U, Steene-Johannessen J, Brown WJ, Fagerland MW, Owen N, Powell KE, et al. Does physical activity attenuate, or even eliminate, the detrimental association of sitting time with mortality? A harmonised meta-analysis of data from more than 1 million men and women. Lancet. 2016;388:1302-10

35. López-González D, Partida-Gaytán A, Wells JC, Reyes-Delpech P, Avila-Rosano F, Ortiz-Obregón $\mathrm{M}$, et al. Obesogenic lifestyle and its influence on adiposity in children and adolescents, evidence from Mexico. Nutrients. 2020;12:819.

36. Bueno AL, Czepielewski MA. The importance for growth of dietary intake of calcium and vitamin D. J Pediatr (Rio J). 2008:84:386-94.

37. Harel Z, Riggs S, Vaz R, White L, Menzies G. Adolescents and calcium: what they do and do not know and how much they consume. J Adolesc Health. 1998;22:225-8.

38. Bandini LG, Must A, Cyr H, Anderson SE, Spadano JL, Dietz WH. Longitudinal changes in the accuracy of reported energy intake in girls 10-15 y of age. Am J Clin Nutr. 2003;78:480-4.

39. Forrestal SG. Energy intake misreporting among children and adolescents: a literature review. Matern Child Nutr. 2011;7:112-27. 